\title{
EFFECT OF FERTILIZATION WITH SURGE FLOW TECHNIQUE ON APPLICATION EFFICIENCY, WATER PRODUCTIVITY, YIELD AND IRRIGATION COST OF MAIZE CROP (ZEA MAYS L.)
}

\author{
Abdelaziz M. Okasha ${ }^{1{ }^{*}}$, El-Said M. Khalifa ${ }^{2}$, Moustafa M. Moustafa ${ }^{3}$, Mohamed S. Khattab \\ ${ }^{1}$ Assoc. Prof., Ag. Eng. Dept., Fac. of Ag., Kafrelsheikh U., Kafrelsheikh, Egypt. \\ ${ }^{2}$ Prof., Ag. Eng. Dept., Fac. of Ag., Kafrelsheikh U., Kafrelsheikh, Egypt. \\ ${ }^{3}$ Chief Researcher, Ag. Eng. Res. Inst., Ag. Res. Center, Giza, Egypt. \\ ${ }^{4}$ Assist. Researcher, Ag. Eng. Res. Inst., Ag. Res. Center, Giza, Egypt. \\ *E-mail: abdelaziz.okasha@agr.kfs.edu.eg
}

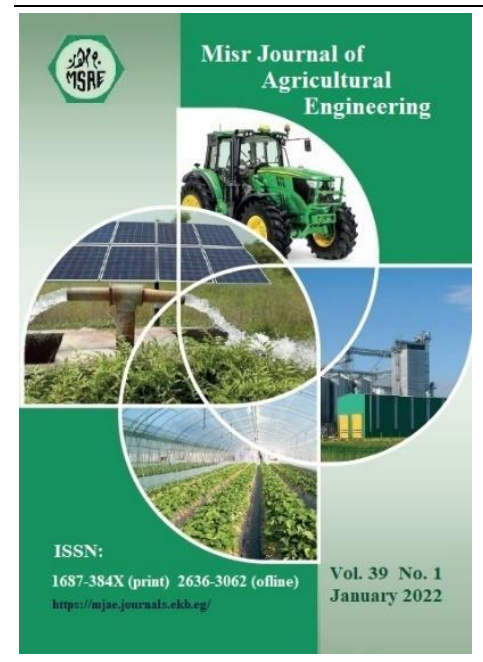

(C) Misr J. Ag. Eng. (MJAE)

\section{Keywords:}

Surge flow; Chemicals application efficiency;

Water productivity; Irrigation cost;

Maize crop (Zea Mays L.).

\section{ABSTRACT}

The development of equipment and management guidelines for surge flow irrigation has made it possible to save more irrigation water and enhance efficiency of fertilizers application. In the context, the experiment was carried out at Gharbia Province, Egypt during the growing season of 2017/2018. The overall aim was to improve management of fertigation through surge flow technique to reduce advance time, maximize fertigation application efficiency, water productivity and minimize cost of irrigation in comparison to continuous furrow irrigation under clay loam textured soil conditions for maize crop production in the Delta of Egypt. Treatments were three discharge rates of irrigation water mainly $0.56,0.75$ and $0.95 \mathrm{~L} / \mathrm{s}$, with 4,5 and 6 pulses and chemical injected surges of $2^{\text {nd }}, 3^{\text {rd }}, 4^{\text {th }}$ and $5^{\text {th }}$ in a 140 meters long furrows. The Results showed that surge flow irrigation technique with 6 surges reduced advance time by 8.7 , 8.8 and $5.5 \%$ of continuous flow under different discharge rates of $0.56,0.75$ and $0.95 \mathrm{~L} / \mathrm{s}$, respectively. The greatest value of chemicals application efficiency of $91 \%$ was obtained under discharge rate of $0.56 \mathrm{~L} / \mathrm{s}$ with 6 surges during the $4^{\text {th }}$ fertilized injected surge. The highest water productivity value of $1.83 \mathrm{~kg} / \mathrm{m}^{3}$ was obtained by the treatment of 6 pulses with $0.95 \mathrm{~L} / \mathrm{s}$ flow rate at fertilization in the fourth pulse compared with all other treatments. The highest irrigation cost of 924.5L.E/fed/season was recorded under discharge of $0.56 \mathrm{~L} / \mathrm{s}$ with continuous flow irrigation compared with the lowest of 679.7L.E/fed/season which was noticed with 6 pulses treatment at discharge of $0.95 \mathrm{~L} / \mathrm{s}$.

\section{INTRODUCTION}

$\mathrm{E}$ conomic and sustainable development mainly depend on water, and as water demand grows, it is crucial to use it more efficiently. If Egypt does not succeed in formulating and implementing a water resource management strategy that can match the limited freshwater supply with the increasing demand, the future looks bleak. At the moment, Egypt 
is almost entirely reliant on Nile River's water, with a share of flow of roughly 55.5 billion $\mathrm{m}^{3} /$ year, as well as small amounts of rainfall, floodwater, groundwater, agricultural drainage water, desalination, and treated municipal water. According to new programmers, all of the valley's land, the delta, and new reclaimed lands that are suitable for modern irrigation systems will be served by new irrigation systems. In the Northern Delta, our governorates are able to maintain modern irrigation systems due to the lack of interference from sea water. Chemigation refers to the injection of various water-soluble chemicals, such as fertilizers or soil amendments, into agricultural irrigation systems. Humpherys (1989) revealed that the surge flow technique may be particularly useful for fine-textured or consolidated soils with low infiltration rates, or for short fields that would normally produce more runoff. As a result, the size of the advance stream is chosen with the goal of controlling runoff rather than a rapid advance. For a furrow to be non-erosive, stream sizes calculated using this method must be smaller than non-erosive stream sizes. Gascho and Mashail (1991) mentioned that fertigation (is the application of fertilizer in irrigation water or through irrigation systems at a time when crops need it) is a common practice. As part of this definition, both surface irrigation methods and pressurized irrigation systems are included. United States Department of Interior, USDI, (1993) stated that in surge flow irrigation, 4 to 6 surges are recommended to advance water to the end of the furrow. With this number of surges, irrigation efficiency and distribution uniformity are expected to be the highest. Boldt et al. (1994) explained, in order to evaluate fertigation treatments, the application efficiency of the low quarter (AELQ) was used. As a result of simulations, fertigation can occur during any portion or all of the on-time of a surge cycle, but it should be applied for the entire irrigation period in order to achieve the best $\mathrm{N}$ efficiency. If the soil has a low intake rate, fertigation should be applied during all of the ontime of a surge cycle. Kanber et al. (2001) concluded that surge flow treatments were more effective at application than continuous flow treatments, and that surge flow treatments reduce clay soil percolation losses by 19-20\%. Rasoulzadeh and Sepaskhah (2003) scaled infiltration equations for furrow irrigation. In surge irrigation, saturated hydraulic conductivity and final infiltration rate were considered to be $80 \%$ of those in a continuous furrow. Scaled infiltration equations cannot be applied to a heavily cracked clay soil where initial infiltration occurs through the cracks rather than through the matrix, which is noteworthy. Ismail (2004) reported that as a result of the system and the land's contour, fertilizer application efficiency can vary greatly. In some cases, surge fertigation may result in less runoff of fertilizer and more uniform application of the fertilizer. However, even with surge fertigation, some fertilizer runoff is possible. Sabillon and Merkley (2004) stated that, for a furrow irrigation and fertigation system to be successful, it must be designed and managed in a way that ensures efficient and uniform application and distribution of water and fertilizer, as well as minimal surface runoff and leaching below the crop root zone. Eldeiry et al. (2005) showed that it is important to consider the optimal application rate and feasible furrow length given ownership boundaries and/or topography when Egypt's farmers begin implementing longer furrow lengths. Smith et al. (2005) demonstrated that surface systems are simple, consume little energy, and have a low initial capital requirement. However, they are frequently associated with a high labor requirement and low water use efficiency. Sial, et al. (2006) found that surge irrigation saves $13.92 \%$ more time than continuous flow irrigation 
in advancing the water front on previously irrigated wet areas. Horst et al. (2007) reported that continuous flow treatment, deep percolation was high, but surge flow irrigations were low. Hou et al. (2007) focused on the timing of fertigation during an irrigation cycle and the resulting availability of applied fertilizers to plants. Nitrogen application at the begin of an irrigation cycle improves cotton $\mathrm{N}$ uptake and nitrogen use efficiency with drip irrigation. Kifle et al. (2008) pointed out that surge flow irrigation saved more water and increased yields than continuous flow irrigation. Farmers can use it in areas where irrigation water is a problem for crop production. Perea et al. (2011) developed a cross-sectional averaged advection dispersion equation model, for furrow irrigation. Pulses could reduce leaching and runoff losses in surface irrigation systems, according to an evaluation of several fertigation strategies. Shock and Welch (2011) said that the timing of fertilizer addition, they, is crucial. Too early in the surge cycle, fertilizer may be applied at the top of the furrow or too deeply in the root zone. This is because fertilizer is evenly distributed and remains in the upper part of the soil profile, minimizing loss to deep percolation. Siyal et al. (2012) found that water infiltration into the soil profile in standard irrigation furrows is driven by gravitational forces in the downward vertical direction and by capillary forces horizontally and upward into the ridge. Vertically downward infiltration is reduced or eliminated in furrows. Soroush et al. (2012) recommended that fertigation should be applied at the end of an irrigation event to avoid fertilizer leaching into groundwater. Given the widespread use of irrigated furrows around the world, furrow fertigation has the potential to become a cost-effective method of fertilizer application in agricultural fields. Moustafa (2013) mentioned that pulsed irrigation can be used to develop surface irrigation systems in reclaimed sandy areas using classified pipes for water distribution with fertilizer and chemical addition and injection through chemical irrigation technology "fertigation and chemigation", according to the expert. Valipour (2013) referred It was determined that different types of inflow regimes were used to increase irrigation efficiency in border irrigation. Using SIRMOD as a simulation tool, it was found that cutback irrigation methods increased irrigation efficiency by $11.66 \%$, while surge irrigation methods reduced inflow rate by $16.6 \mathrm{~m}^{3}$ and $6.7 \mathrm{~m}^{3}$. Ebrahimian et al. (2014) reviewed and classified recommendations based on the type of surface irrigation system being considered. Inflow hydrograph, soil and water quality, effective root depth for fertilizer uptake, and the specific surface irrigation method are all factors affecting surface fertigation performance. FAO (2015) stated that worldwide, fertilizer demand is expected to increase by $25 \%$ over the next decade, which will lead to increase the risk of nutrient pollution of water bodies. In order to achieve this, irrigation and fertigation management strategies must be transformed into ones that are more efficient and sustainable. Amer et al. (2017) mentioned that in Egypt the total irrigated area is approximately 3.60 million hectares (8.64 million feddan), and rainfed area is approximately 84,000 hectares (200,000 feddan). It is estimated that as much as $35 \%$ of cultivated lands is salinized because salts accumulate mostly at the soil surface. Salinized soils dominate the Nile Delta's north central region, as well as its eastern and western flanks. Amer and Attafy (2017) reported that surge flow advanced more rapidly than the corresponding continuous flow, according to the study. Surge flow treatments reached the tail end of the furrow faster than continuous flow treatments. Improving performance indices such as water needed per irrigation, irrigation requirements per season, 
surface runoff and application efficiency as well as distribution uniformity were achieved through the use of surge irrigation technique. Khalifa et al. (2019) found that corn crop water productivity was affected by irrigation systems. Under surge flow irrigation with a $40 \mathrm{~m}$ furrow length and a $12.24 \mathrm{~L} / \mathrm{s}$ discharge rate, the highest water productivity was recorded at $1.7 \mathrm{~kg} / \mathrm{m}^{3}$. The values of water productivity decreased by $24 \%$ when discharge rate increased from 12.24 to $44.40 \mathrm{~L} / \mathrm{min}$. Mohammadi, et al. (2019) showed that managing water and fertilizer at the same time had a significant impact on water productivity and yield of corn. The treatment of wide ridges with optimal irrigation and ridge fertilization resulted in the highest grain yield and water productivity increases of $44.2 \%$ and $67.4 \%$, respectively. Rao, et al. (2019) proved that a 78 percent water savings when using alternate furrow with surge flow irrigation, according to the study. For Fennel (Foeniculum vulgare Mill.), the surge flow, alternate furrow irrigation method increased water productivity and amount earned per unit of water by four times over the check basin method of irrigation. Spencer, et al. (2019) studied in a five-year experiment corn grain yield, total water applied, irrigation water use efficiency, and net returns above irrigation costs. Total water applied was reduced by $39.5 \%$, corn grain yield increased by $403.5 \mathrm{~kg} / \mathrm{ha}$, and irrigation water efficiency was increased by $51.3 \%$, resulting in high net returns above irrigation costs. Ojaghlou et al. (2020) developed a fertigation model to assess the effect of surge flow irrigation on furrow fertigation. In furrow irrigation with a surge flow, fertilization during all advance surges was recognized as the preferred option. Zamora-Re et al. (2020) decided that irrigation was essential in Florida's maize production in order to achieve high yields. Comparatively to typical irrigation practices in the region, reducing irrigation amounts by 36 to $47 \%$ did not have a negative effect on maize growth and yield.

According to previous studies, traditional furrow irrigation methods have limited water and chemical distribution potential and are non-uniform along the furrow in most cases. When it comes to surface irrigation, chemigation is used much less frequently than drip and sprinkler irrigation. Recently, the development of surge flow irrigation equipment and management guidelines has made it possible to apply water and chemicals more uniformly than with conventional furrow irrigation, increasing the efficiency of chemical distribution in the root zone of plants. To overcome the problem of surface runoff and deep soil leakage, giving less chance of loss of fertilizers and chemicals and reducing environmental pollution in groundwater. In addition, operating costs and capital expenditures are usually lower than other irrigation systems. These additional water demands require an increased efficiency in water use. One of the measures is to improve irrigation methods at field scale in order to obtain higher efficiency. Another way to save more water for irrigation is using surge irrigation method. Consequently, the objectives of the present work were to improve water productivity, chemicals application efficiency and distribution uniformity through surge flow technique. Additionally, study the effect of on-off time and number of surges $(4,5$ and 6 pulses) with different discharge rates. Moreover, study the effect of timing for injected chemicals through surge technique under different injected surges for each discharge rate and number of surges. Finally, estimate a cost analysis of irrigation techniques under clay textured soil in the Middle Delta region for corn production. 


\section{MATERIALS AND METHODS}

1. Experimental site: At a private farm located in Tanta, Gharbeia Governorate in the Middle Delta of Egypt (3045'39.9" N latitude, $31^{\circ} 02^{\prime} 35.15^{\prime \prime}$ east latitude with a $9 \mathrm{~m}$ altitude), field experiments were conducted in 2017/2018 growing season. Nine-share chisel plough was used to plough the experimental plots, with two passes and a self-rotary leveling laser to fine level the soil at $0.1 \%$ slope. $0.7 \mathrm{~m}$ spacing and $140 \mathrm{~m}$ length were specified for the $\mathrm{V}$ shaped furrow. Maize (Hybrid 321 variety) was sown on May $15^{\text {th }} 2017$ at a rate of $12 \mathrm{~kg} / \mathrm{fed}$ $(28.56 \mathrm{~kg} / \mathrm{ha})$, and harvested on September $5^{\text {th }}$ 2017. following the recommendations of the Ministry of Agriculture and Land Reclamation, the amount of fertilizer needed was taken into consideration. In the present study, Super Phosphate $\left(15.55 \% \mathrm{P}_{2} \mathrm{O}_{5}\right)$ was added to soil during seedbed preparation, Ammonium Nitrates $(32.5 \% \mathrm{~N})$ and Potassium Sulfates $\left(48 \% \mathrm{~K}_{2} \mathrm{O}\right)$ were added to irrigation water as fertilizers, and their concentrations were extracted using (AB-DTPA) and measured using atomic absorption spectrometry (AAS).

2. Physical and chemical analysis of soil and chemical analysis for irrigation water: Laboratory of Soil, Water and Environmental Research Institute determined some physical and chemical properties of the experimental soil as presented in Tables 1, 2 and 3. Soil texture triangle was used to determine the soil texture which was identified as "clay".

The following equation was used to calculate the amount of readily available water (RAW) (James 1988):

$$
\mathrm{RAW}=\frac{(\mathrm{MAD})\left(\mathrm{D}_{\mathrm{rz}}\right)(\mathrm{FC}-\mathrm{PWP})}{100}
$$

Where: RAW: Readily available water, cm; MAD: Maximum allowable deficiency ( 0.65 for corn); Drz: Depth of the root zone, cm; FC: Field capacity by volume, $\%$ and PWP: Permanent wilting point, $\%$.

Table 1: Some Physical properties of the investigated soil

\begin{tabular}{|c|c|c|c|c|c|c|c|c|}
\hline \multirow{2}{*}{$\begin{array}{c}\text { Depth, } \\
\mathrm{cm}\end{array}$} & \multicolumn{3}{|c|}{$\begin{array}{c}\text { Particle size } \\
\text { distribution, }\end{array}$} & Texture & $\begin{array}{c}\text { Bulk } \\
\text { density, } \\
\mathrm{g} / \mathrm{cm}^{3}\end{array}$ & $\begin{array}{c}\text { Field } \\
\text { capacity, } \\
\%\end{array}$ & $\begin{array}{c}\text { PWP, } \\
\%\end{array}$ & $\begin{array}{c}\text { RAW, } \\
\mathrm{cm}\end{array}$ \\
\cline { 2 - 9 } & Sand & Silt & Clay & & 1.16 & 43.7 & 21.3 & 2.18 \\
\hline $0-15$ & 22.8 & 30.4 & 46.8 & Clay & 16.1 & 19.7 & 1.99 \\
\hline $15-30$ & 24.8 & 29.1 & 46.1 & Clay & 1.20 & 40.1 & 17.3 & 2.05 \\
\hline $30-45$ & 25.3 & 29.5 & 45.2 & Clay & 1.22 & 38.3 & 17.8 \\
\hline $45-60$ & 28.8 & 28.6 & 42.6 & Clay & 1.25 & 36.1 & 16.8 & 1.88 \\
\hline Average/15cm & 25.4 & 29.4 & 45.2 & Clay & 1.2 & 39.4 & 18.7 & 2.02 \\
\hline Total & \multicolumn{9}{|c|}{} \\
\hline
\end{tabular}

PWP: Permanent wilting point; RAW: Readily available water

Table 2: Some chemical properties of the investigated soil

\begin{tabular}{|c|l|l|c|c|c|c|c|c|c|}
\hline \multirow{2}{*}{$\begin{array}{c}\text { Depth, } \\
\mathrm{cm}\end{array}$} & \multirow{2}{*}{$\begin{array}{l}\mathrm{EC}, \\
\mathrm{ds} / \mathrm{m}\end{array}$} & $\mathrm{PH}$ & \multicolumn{4}{|c|}{ Cations, meq/L } & \multicolumn{3}{|c|}{ Anions, meq/L } \\
\cline { 4 - 11 } & & & $\mathrm{Ca}^{++}$ & $\mathrm{Mg}^{++}$ & $\mathrm{Na}^{+}$ & $\mathrm{K}^{+}$ & $\mathrm{HCO}_{3}^{-}$ & $\mathrm{CL}^{-}$ & $\mathrm{SO}_{4}^{-}$ \\
\hline $0-15$ & 1.2 & 7.7 & 5.2 & 2.2 & 4.1 & 1.6 & 7.3 & 4.5 & 1.3 \\
\hline $15-30$ & 1.3 & 7.7 & 8.4 & 3 & 5 & 1.6 & 8.1 & 8.6 & 1.3 \\
\hline $30-45$ & 1.3 & 7.7 & 7.8 & 3.3 & 5.4 & 2.3 & 8.3 & 8.9 & 1.6 \\
\hline $45-60$ & 1.2 & 7.6 & 4.9 & 4.1 & 6.4 & 1.1 & 9 & 5.4 & 2.1 \\
\hline Average & 1.25 & 7.67 & 6.6 & 3.2 & 5.2 & 1.7 & 8.2 & 6.9 & 1.6 \\
\hline
\end{tabular}


Table 3: Chemical analysis for irrigation water

\begin{tabular}{|c|c|c|c|c|c|c|c|c|}
\hline \multirow{2}{*}{$\begin{array}{c}\mathrm{EC}, \\
\mathrm{ds} / \mathrm{m}\end{array}$} & \multirow{2}{*}{$\mathrm{pH}$} & \multicolumn{4}{|c|}{ Cations (meq/L) } & \multicolumn{3}{|c|}{ Anions (meq/L) } \\
\cline { 3 - 9 } & & $\mathrm{Ca}^{++}$ & $\mathrm{Mg}^{++}$ & $\mathrm{Na}^{+}$ & $\mathrm{K}^{+}$ & $\mathrm{HCO}_{3}^{-}$ & $\mathrm{CL}^{-}$ & $\mathrm{SO}_{4}^{-}$ \\
\hline 0.38 & 8.10 & 4.00 & 2.60 & 1.76 & 0.24 & 2.80 & 2.00 & 4.27 \\
\hline
\end{tabular}

Using the double ring method, the cumulative infiltration and infiltration rate were measured, as illustrated in Figure 1. The infiltration rate was averaged $4 \mathrm{~cm} / \mathrm{h}$.

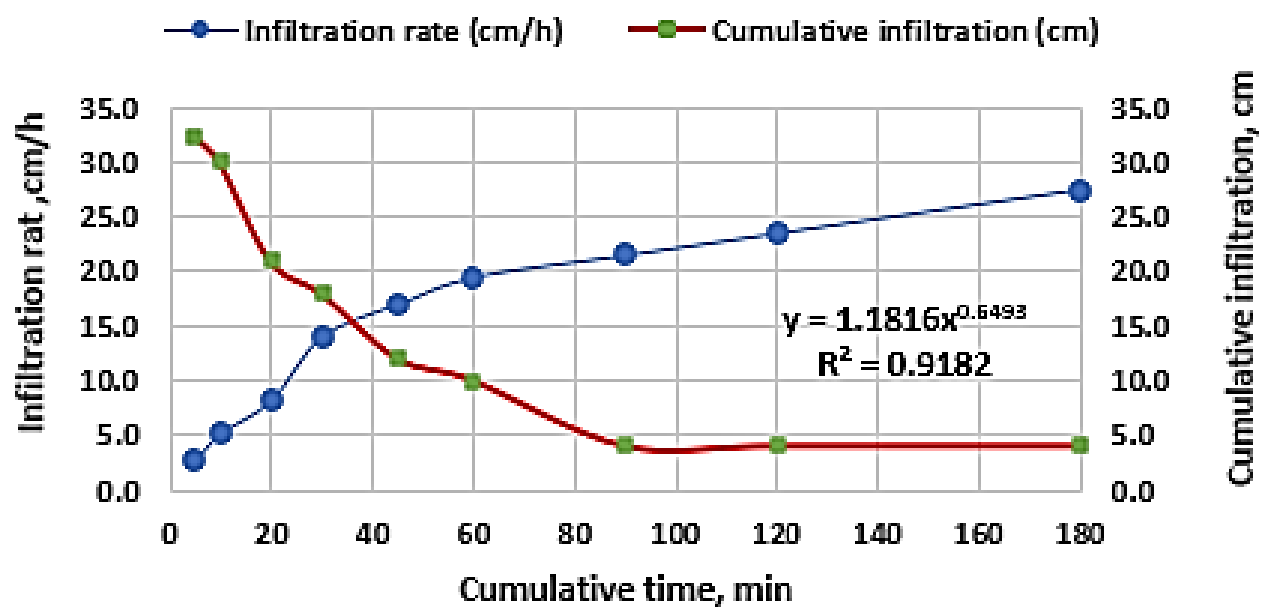

Figure 1: Cumulative infiltration and infiltration rate for soil of experimental site

3. Irrigation system installation, experimental treatments and chemical injection method: Traditional furrow irrigation system with surge flow technique was considered in the present study. Furrow length was $140 \mathrm{~m}$ and $0.7 \mathrm{~m}$ distance between furrows as shown in Figure 2. A Centrifugal pump, was operated by A $6.5 \mathrm{hp}(4.8 \mathrm{~kW})$ gasoline engine, 4-inch diameter of outlet, 2.8 bar maximum delivery lift, $7 \mathrm{~m}$ and suction height and maximum water output $90 \mathrm{~m}^{3} / \mathrm{h}$ to deliver water to the experimental plots.

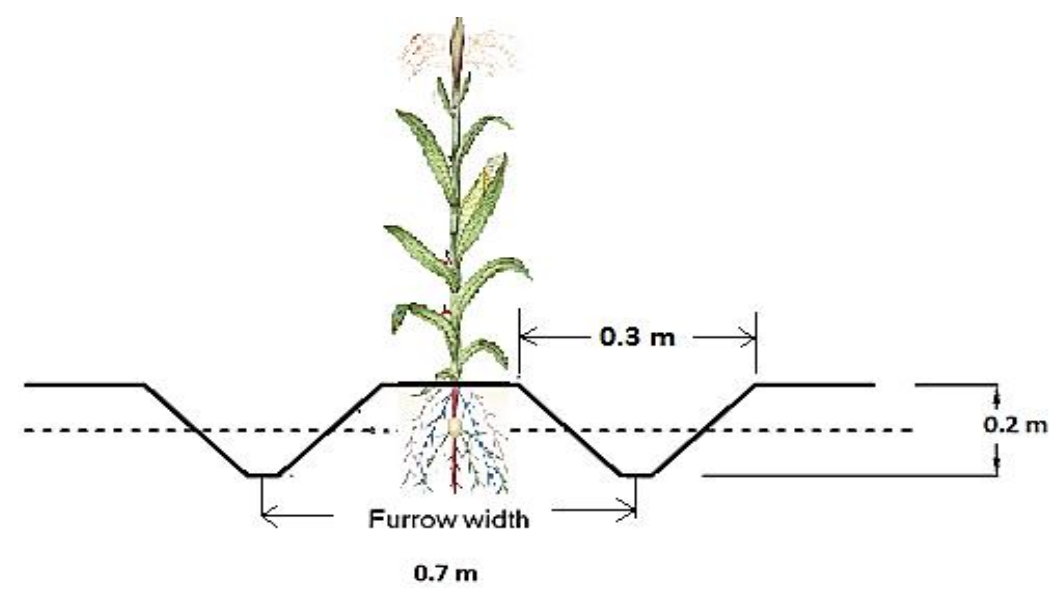

Figure 2: Geometry of furrow irrigation

PVC gated pipes of $110 \mathrm{~mm}$ diameter were constructed at the head of the field experiment to convert water through gates manual control. The amount of applied water was calculated every irrigation event. A volumetric method was applied to measure discharge rate for furrow 
irrigation by set of 1-, 1.5- and 2-inch manual valves on mainline, and determining the time needed to fill $20 \mathrm{~L}$ tank with five replications. The field treatments were designed as a splitsplit plot experimental design. Main plots were assigned for the discharge rate. Three different discharges were used in the present study $(0.56,0.75$ and $0.95 \mathrm{~L} / \mathrm{s})$ and symbolled as Q1, Q2 and Q3, respectively. Sub-main plots were allocated for the number of surges, where three number of surges were used 4, 5 and 6 surges (S1, S2 and S3) based on the guidelines of the USD1, (1993) for surge flow irrigation. the recommended number of surges to advance water to the end of the furrow ranges from 4 to 6 surges. Sub-sub-main plot were used for injected chemical surges, where $2^{\text {nd }}$ and $3^{\text {rd }}$ surges for treatment of 4 surges, $2^{\text {nd }}, 3^{\text {rd }}$ and $4^{\text {th }}$ surges for treatment of 5 surges, $2^{\text {nd }}, 3^{\text {rd }}, 4^{\text {th }}$ and $5^{\text {th }}$ surges for treatment of 6 surges. Generally, the first and last surges of irrigation were not used for chemigation. Continuous furrow irrigation (C) was used as the control treatment. All treatments were replicated three times. There are experimental treatments in Table 4 and on/off/total time; irrigation rate; and chemical injection rate. Figure 3 shows the experimental setup for pump station and treatments. Discharge rate of Q2 and Q3 are located next to Q1 but are not shown in the schematic diagram, because they have the same form of Q1. Also, Figure 3 shows two tanks of 200 liters capacity connected together by a $16 \mathrm{~mm}$ hose by-pass valves in order to isolate the tank output chemicals. Both tanks were placed one and a half meters above the soil surface, with valves calibrated in liters, and fertilizer solution was allowed to flow by gravity through some form of a constant head metering valve into an open channel for ease of use and efficiency. Injection of the fertilizers at the appropriate rate, which will depend on how much water is discharged and what concentration was needed to be injected during the runoff cycle.

Table 4: Experimental design

\begin{tabular}{|c|c|c|c|c|c|c|}
\hline $\begin{array}{c}\text { Discharges, } \\
\mathrm{L} / \mathrm{s}\end{array}$ & $\begin{array}{l}\text { No. of } \\
\text { surges }\end{array}$ & $\begin{array}{l}\text { No. of injected } \\
\text { chemicals surges }\end{array}$ & $\begin{array}{c}\text { On- } \\
\text { time } \\
\text { period, } \\
\text { min }\end{array}$ & $\begin{array}{c}\text { Off- } \\
\text { time } \\
\text { period, } \\
\text { min }\end{array}$ & $\begin{array}{c}\text { Total } \\
\text { irrigation } \\
\text { time, } \\
\text { min }\end{array}$ & $\begin{array}{c}\text { Chemicals } \\
\text { injected } \\
\text { rates, L/h }\end{array}$ \\
\hline \multirow{4}{*}{0.56} & 4 & $2^{\text {nd }}$ and $3^{\text {rd }}$ surges & 78 & 10 & 291 & 38.40 \\
\hline & 5 & $\begin{array}{c}2^{\text {nd }}, 3^{\text {rd }} \text { and } 4^{\text {th }} \\
\text { surges }\end{array}$ & 54 & 10 & 207 & 55.37 \\
\hline & 6 & $\begin{array}{c}2^{\text {nd }}, 3^{\text {rd }}, 4^{\text {th }} \text { and } 5^{\text {th }} \\
\text { surges }\end{array}$ & 41 & 10 & 159 & 72.15 \\
\hline & Continuous & - & 62 & - & 286 & 48.00 \\
\hline \multirow{4}{*}{0.75} & 4 & $2^{\text {nd }}$ and $3^{\text {rd }}$ surges & 43 & 10 & 201 & 69.21 \\
\hline & 5 & $\begin{array}{c}2^{\text {nd }}, 3^{\text {rd }} \text { and } 4^{\text {th }} \\
\text { surges }\end{array}$ & 33 & 10 & 151 & 90.19 \\
\hline & 6 & $\begin{array}{c}2^{\text {nd }}, 3^{\text {rd }}, 4^{\text {th }} \text { and } 5^{\text {th }} \\
\text { surges }\end{array}$ & 52 & 10 & 283 & 57.60 \\
\hline & Continuous & - & 36 & - & 196 & 83.06 \\
\hline \multirow{4}{*}{0.95} & 4 & $2^{\text {nd }}$ and $3^{\text {rd }}$ surges & 28 & 10 & 156 & 108.23 \\
\hline & 5 & $\begin{array}{l}2^{\text {nd }}, 3^{\text {rd }} \text { and } 4^{\text {th }} \\
\text { surges }\end{array}$ & 155 & 10 & 310 & 19.20 \\
\hline & 6 & $\begin{array}{c}2^{\text {nd }}, 3^{\text {rd }}, 4^{\text {th }} \text { and } 5^{\text {th }} \\
\text { surges }\end{array}$ & 108 & 10 & 215 & 27.69 \\
\hline & Continuous & - & 83 & - & 165 & 36.08 \\
\hline
\end{tabular}




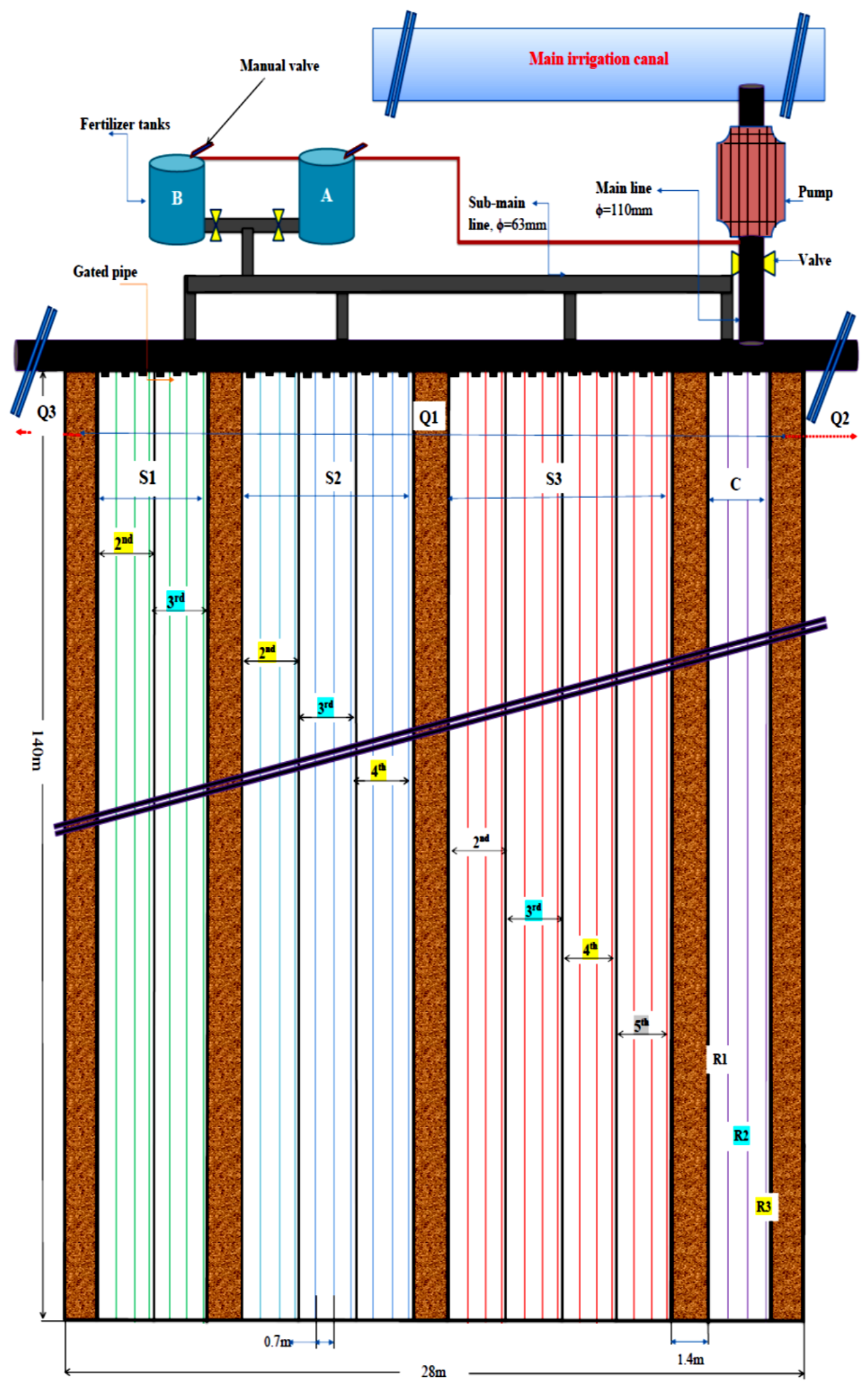

Figure 3: A schematic diagram of the experimental construction and design 
Estimation of water requirements: Penman-Monteith method was used to calculate water consumption, mm/day, (Allen et al. 1998). The following formula (Doorenbos and Pruitt, 1977) was used to calculate crop evapotranspiration (ETc) from the obtained meteorological data listed in Table 5.

$$
\mathrm{ET}_{\mathrm{C}}=\mathrm{ET}_{0} \times \mathrm{K}_{\mathrm{c}}
$$

Where: ET $\mathrm{T}_{\mathrm{c}}$ Evapotranspiration for a specific crop (mm/day); $\mathrm{ET}_{\mathrm{o}}$ : Reference evapotranspiration ( $\mathrm{mm} /$ day) and $\mathrm{K}_{\mathrm{c}}$ : Crop coefficient (dimensionless).

A crop coefficient values for maize crop was used based on the crop growth stage according to (Allen et al., 1998). Values of $K_{c}$ and water consumptive use are presented in Table 5. The Penman-Monteith method was used to calculate the evapotranspiration of maize crop using the FAO CROPWAT software, as presented in Table 6.

Table 6: Calculated water consumption use for maize crop

\begin{tabular}{|c|c|c|c|c|c|}
\hline Growth stage & $\begin{array}{c}\mathrm{ET}_{\mathrm{o}} \\
\mathrm{mm} / \text { day }\end{array}$ & $\begin{array}{c}\mathrm{K}_{\mathrm{c}} \\
\text { for } \\
\text { growth } \\
\text { stage } \\
\end{array}$ & $\begin{array}{c}\mathrm{ET}_{\mathrm{c}} \\
\mathrm{mm} / \mathrm{day}\end{array}$ & $\begin{array}{l}\text { Total } \\
\text { ET }_{\mathrm{c}} \\
\text { Period } \\
(\mathrm{mm})\end{array}$ & $\begin{array}{l}\text { Note; water } \\
\text { applied of the first } \\
\text { irrigation for all } \\
\text { treatments }(\mathrm{mm})\end{array}$ \\
\hline $\begin{array}{c}\text { Initial } \\
15 / 5 / 2017- \\
5 / 6 / 2017\end{array}$ & 5.69 & 0.3 & 1.71 & 34.2 & \multirow{4}{*}{107.15} \\
\hline $\begin{array}{c}\text { Mid-season } \\
6 / 6 / 2017- \\
24 / 7 / 2017 \\
\end{array}$ & 5.46 & 1.15 & 6.28 & 301.44 & \\
\hline $\begin{array}{l}\text { End / Late } \\
25 / 7 / 2017- \\
20 / 8 / 2017\end{array}$ & 4.31 & 1.05 & 4.53 & 113.25 & \\
\hline \multicolumn{4}{|c|}{$\mathrm{ET}_{\mathrm{c}, \mathrm{mm}} / \mathrm{season}$} & 448.89 & \\
\hline
\end{tabular}

4.1 Available water: Water between the field capacity and the permanent wilting point was defined as available water (James, 1988).

$$
\mathrm{AW}=\frac{\mathrm{RAW}}{\mathrm{MAD}}
$$

Where: RAW: Readily available water (cm) and MAD: Maximum allowable deficiency $(0.65$ for corn).

4.2 Irrigation intervals: As a direct method of irrigation, soil moisture depletion in the effective root zone determines irrigation intervals for a given crop, as well as weather conditions, soil texture, and crop characteristics (Doorenbos et al., 1979) calculated the following:

$$
\mathrm{Cu}=\frac{\mathrm{FC}-\mathrm{W} 1}{100} \times \rho_{\mathrm{b}} \times \mathrm{d}
$$


Where: $\mathrm{Cu}$ : Consumptive use (cm); FC: Field capacity for each soil layer (\%) W1: Soil moisture content before irrigation $(\%) ; \rho_{\mathrm{b}}$ : Bulk density of the specific soil layer, (dimensionless) and D: depth of each soil layer, $15 \mathrm{~cm}$.

The irrigation intervals were calculated using the following equation:

$$
\mathrm{I}=\frac{\mathrm{RAW}}{\mathrm{ET}_{\mathrm{a}}} \times \mathrm{E}_{\mathrm{i}}
$$

Where: I: Intervals between two irrigations (day); RAW: Really available soil water $(\mathrm{cm})$; $\mathrm{ET}_{\mathrm{a}}$ : Actual evapotranspiration, $\mathrm{ET}_{\mathrm{a}}=\mathrm{ET}_{\mathrm{o}} \times \mathrm{K}_{\mathrm{c}}(\mathrm{mm} / \mathrm{day}) ; \mathrm{K}_{\mathrm{c}}$ : Crop coefficient, and Ei: Irrigation efficiency (60\% for surface irrigation).

Irrigation water requirements were calculated according to the following equation:

$$
\mathrm{W} . \mathrm{R}=\mathrm{ET}_{\mathrm{a}} \times \mathrm{I}(1+\mathrm{L} . \mathrm{R}) \times 4.2
$$

Where: W.R: Water requirement $\left(\mathrm{m}^{3} / \mathrm{fed}\right)$; and L.R: Leaching requirement, \%, I: Intervals between two irrigation (day); $\mathrm{ET}_{\mathrm{a}}$ : Actual evapotranspiration(mm/day) and 4.2 converted constant.

4.3 Applied irrigation water: It was calculated by the following equation:

$$
\mathrm{Q}=\mathrm{q} \times \mathrm{T} \times \mathrm{N}
$$

Where: Q: Water volume (L/plot); T: Total time irrigation per furrow, (min); N: Number of furrows per each plot and Q: Irrigation discharge per furrow, (L/min).

5. Soil moisture: The soil moisture percentage was determined gravimetrically at three points along the furrow $(35,70$ and $105 \mathrm{~m})$. Before and 48 hours after each irrigation event, soil samples were taken at three points along the furrow and at four depths in the root zone $(0-15$, 15-30, 30-45 and 45-60 cm). The samples were usually taken from the field at intervals of varying depths. The soil sample was weighed and placed in an oven at $105^{\circ} \mathrm{C}$. Usually, soil samples are dried in the oven for 24 hours before being reweighed. To determine moisture content on a dry mass basis, the results are expressed as a ratio of the mass of water lost to the mass of dry soil, according to Michael, 1978 as follows:

$$
\theta_{\mathrm{m}}=\frac{\mathrm{M}_{\mathrm{w}}-\mathrm{M}_{\mathrm{d}}}{\mathrm{M}_{\mathrm{d}}} \times 100
$$

Where: $\theta_{\mathrm{m}}$ : Moisture content on dry mass basis (\%); $\mathbf{M}_{\mathrm{w}}$ : Mass of wet sample $(\mathrm{g})$ and $\mathbf{M}_{\mathrm{d}}$ : Mass of oven dry sample $(\mathrm{g})$.

6. Fertilizer injection rate: The fertilizer injection rate was calculated using, Keller and Karameli (1974) equation as follow:

$$
\mathrm{Q}=\frac{\mathrm{F} \times \mathrm{A}}{\mathrm{C} \times \mathrm{T} \times \mathrm{I}} \ldots
$$

Where: Q: Injection rate of completely soluble fertilizer into the irrigation system $(\mathrm{L} / \mathrm{h}) ; \mathrm{F}$ : Fertilizer application rate per irrigation cycle $(\mathrm{kg} / \mathrm{fed})$; A: Irrigation area in limited time (fed.); C: Concentration of the actual nutrients in liquid fertilizer $(\mathrm{kg} / \mathrm{L})$; $\mathrm{T}$ : Irrigation time (h) and I: Ratio between fertilizing and irrigation time. 
7. Advance time: Every four stations along a furrow were timed to determine when the water front reached each furrow (35, 70, 105 and 140m). With the aid of a stopwatch, the on-off cycle time was monitored and controlled. Water advance time was measured and irrigation time was calculated.

8. Chemicals application efficiency: Chemicals application efficiency was determined by the fallowing equation:

$$
\eta_{\mathrm{CA}}=\frac{\mathrm{EC}_{\mathrm{IW}}}{\mathrm{EC}_{\mathrm{SW}}} \times 100
$$

Where: $\eta_{\mathrm{CA}}$ : Chemicals application efficiency $(\%), \mathrm{EC}_{\mathrm{IW}}$ : Electrical conductivity of fertilized irrigation water $(\mathrm{ds} / \mathrm{m})$ and $\mathrm{EC}_{\mathrm{Sw}}$ : Electrical conductivity of soil water content at different depth (ds/m).

Electrical conductivity (EC) for each gravimetric soil samples was measured using EC meter (device model HI 98129). The chemical application pattern (1:5) for each treatment was constructed using the EC values. Air-dried soil samples were then ground. Afterwards, $40 \mathrm{~g}$ of soil was taken to determine the soil's moisture content based on its dry weight. It was mixed with $200 \mathrm{~g}$ of distilled water and an extraction was made. It was determined that the extraction had a conductivity of EC (1:5). A saturated extract, on the other hand, is the expression of electrical conductivity that has reached saturation. During and after fertilization, the electrical conductivity of soil sample was measured in the laboratory.

9. Grain yield $(\mathbf{k g} / \mathbf{f e d})$ : An area of one square meter was used for each treatment to determine the final grain yield, which was then multiplied by the feddan's area.

10. Irrigation water productivity: It was calculated as follows:

$$
\mathrm{IWP}=\frac{\mathrm{Y}}{\mathrm{D}_{\mathrm{ap}}}
$$

Where: IWP: Irrigation water productivity $\left(\mathrm{kg} / \mathrm{m}^{3}\right)$; Y: Crop yield $(\mathrm{kg} / \mathrm{fed})$, and $\mathrm{D}_{\mathrm{ap}}$ : Irrigation water applied $\left(\mathrm{m}^{3} / \mathrm{fed}\right)$.

11. Cost analysis: It was calculated according to (Worth and Xin 1983) partial cost method. Feddan $\left(4200.83 \mathrm{~m}^{2}\right)$ was used to calculate the cost of each treatment, based on the market price level for equipment and installation in 2017. The analysis followed the following outlined procedure:

$$
\text { Initail cost }\left(\frac{\mathrm{L} . \mathrm{E}}{\mathrm{fed}}\right)=\mathrm{INIP} \times \text { Item quantity per fed }
$$

Where: INIP: Irrigation network item price, L.E

Annual fixed cost (F): The following equations were used to calculate the annual fixed costs (L.E./year) of the irrigation system:

$$
\mathrm{F}=\mathrm{D}+\mathrm{I}+\mathrm{T} \text {. }
$$


Where: D: Depreciation rate, (L.E/year); I: The interest, (L.E/year) and T: Taxes and overhead ratio, (L.E/year).

Depreciation cost was calculated using the following equations:

$$
\mathrm{D}=\frac{\mathrm{I} . \mathrm{C}-\mathrm{E} \cdot \mathrm{C}}{\mathrm{E} . \mathrm{L}}
$$

Where: I.C: Initial cost; E.C: Price after the depreciation, (L.E) and E.L = Expected life, (year).

Interest on initial (I) was calculated as follows:

$$
\mathrm{I}=\frac{(\mathrm{I} . \mathrm{C}+\mathrm{E} . \mathrm{C}) \times \mathrm{I} \cdot \mathrm{R}}{2}
$$

Where: I.R: Interest rate/year, (taken 14\%) Taxes and overhead ratio were taken as $1.5 \%$ initial cost.

Operating cost (O): The annual operational cost (L.E/year) of the irrigation system's capital investment was calculated as follows:

$$
\mathrm{O}=\mathrm{L}+\mathrm{E}+(\mathrm{R} \& \mathrm{M})+\mathrm{I} . \mathrm{S}
$$

Where: L: Labor cost, (L.E/year); E: Energy cost, (L.E/year); R\&M: Repair and maintenance cost, (L.E/year) and I.S: Lateral installation cost, (L.E/year). Labor cost was based on two men per irrigation and $\mathrm{R} \& \mathrm{M}$ cost taken as $3 \%$ of initial cost.

The cost of energy was determined as follows:

$$
\mathrm{Bp}=\mathrm{Q} \times \mathrm{TDH} \times \mathrm{K} \times \mathrm{Ei}
$$

Where: $\mathrm{B}_{\mathrm{p}}$ : Break horse power, (hp); Q: Discharge rate, (L/s); TDH: Total dynamic head, (m); $\mathrm{K}$ : Coefficient to convert to energy unit, 1.2 and $\mathrm{E}_{\mathrm{i}}$ : The overall efficiency, $45 \%$ for pump driven by internal combustion engine.

The Energy cost of diesel type source was calculated using the following formula:

$$
\mathrm{E}=1.2 \mathrm{Bp} \times \mathrm{H} \times \mathrm{S} \times \mathrm{F}
$$

Where: E: Energy cost of diesel, (L.E/hp); H: Annual operating hours, (h); S: Specific fuel consumption, (L/h); F: Fuel price, (L.E/h) and 1.2: Factor accounting for lubrication.

Total cost was calculated using the following formula:

$$
\text { Total annual cost }\left(\mathrm{L} \cdot \frac{\mathrm{E}}{\mathrm{year}}\right)=\mathrm{F}+\mathrm{O}
$$

Where: F: Annual fixed cost and O: Operating cost.

$$
\text { Unit production cost }\left(\mathrm{L} \cdot \frac{\mathrm{E}}{\text { ton }}\right)=\frac{\text { Total cost }\left(\mathrm{L} \cdot \frac{\mathrm{E}}{\mathrm{fed}}\right)}{\text { Total yield }\left(\frac{\text { ton }}{\mathrm{fed}}\right)}
$$


12. Statistical analysis: The experiments were laid out in a split-split plot layout. Three discharge rates were assigned to the main plot, while three number of surges were assigned to the sub plots by manual method and the time of injecting chemicals was assigned to the subsub plots. The data was subjected to analysis of variance (ANOVA) and evaluated with the CoStat software for Windows.

\section{RESULTS AND DISCUSSION}

1. Advance time: Figures 4, 5 and 6 show the obtained data. under different discharge rates $(0.56,0.75$, and $0.95 \mathrm{~L} / \mathrm{s})$, all treatments of surge flow irrigation reduced the advance time in comparison to continuous flow, which was 315, 215 and 165 minutes respectively. By increasing the number of surges from 4 to 6 , the advance time decreased from 291, 207, and 159 minutes to 283,196 , and 156 minutes under the same discharge rates of $0.56,0.75$, and $0.95 \mathrm{~L} / \mathrm{s}$, respectively. This means that surge flow technique at 6 surges reduced advance time by $8.7,8.8$, and $5.5 \%$ in comparison to continuous flow under different discharge rates of $0.56,0.75$, and $0.95 \mathrm{~L} / \mathrm{s}$, respectively. These results are in harmony with those obtained by many researchers such as Ismail (2006) and Sharaby (2015). The reduction was due to the effect of off-time, which allows water to infiltrate to soil suction before the second surge begins; the advance time to reach the end of the furrow will be shorter as a result. A decrease in hydraulic conductivity and infiltration rate occurs as soil bulk density increases. The soil particles settle to the bottom of the furrow as a result of the alternating wetting and drying cycle. As these soil particles partially seal the soil surface, the water intake rate is getting lower. Also, as a result of the influence of wetting and drying cycles on soil infiltration characteristics, Kanber et al. (2001) concluded that surge irrigation resulted in a faster water advance than continuous flow.

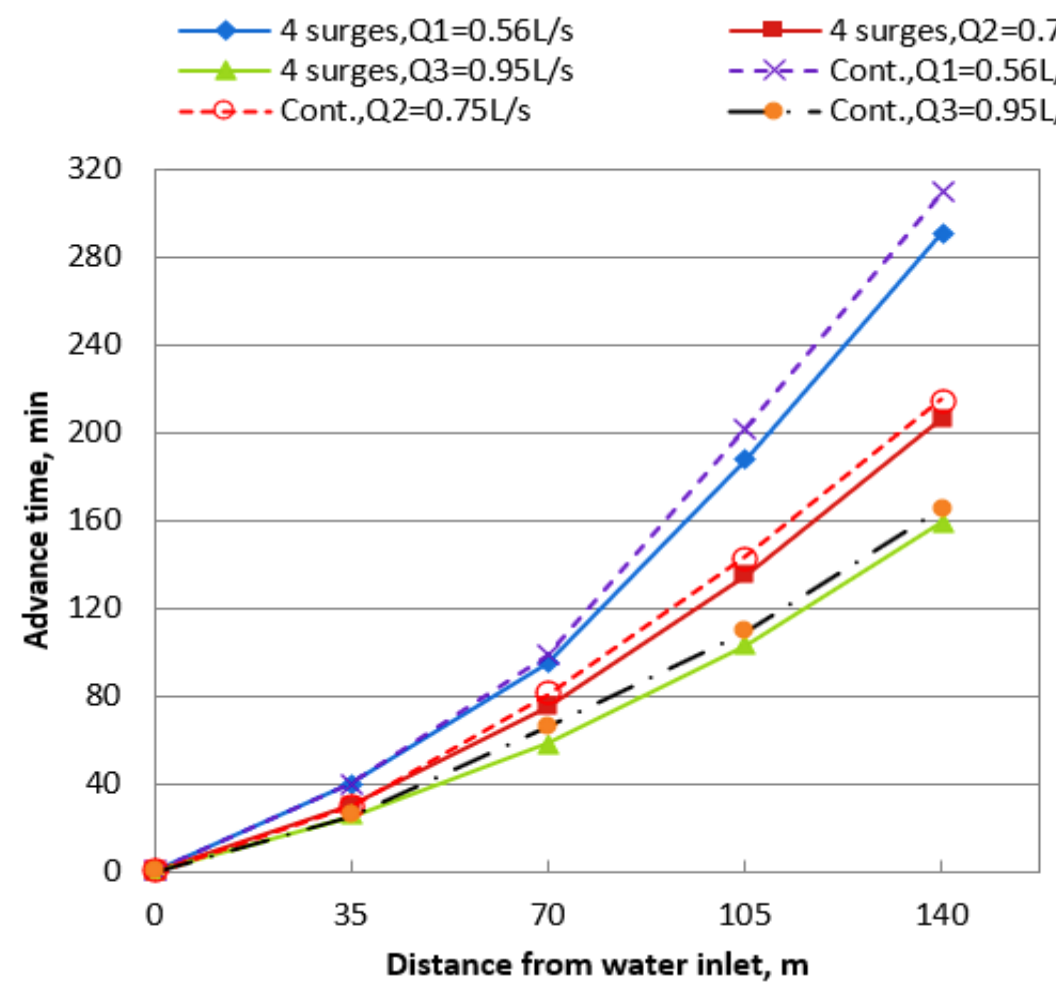

Figure 4: Advance time vs distance from water inlet at different discharge rates with 4 surges and continuous flow irrigation 


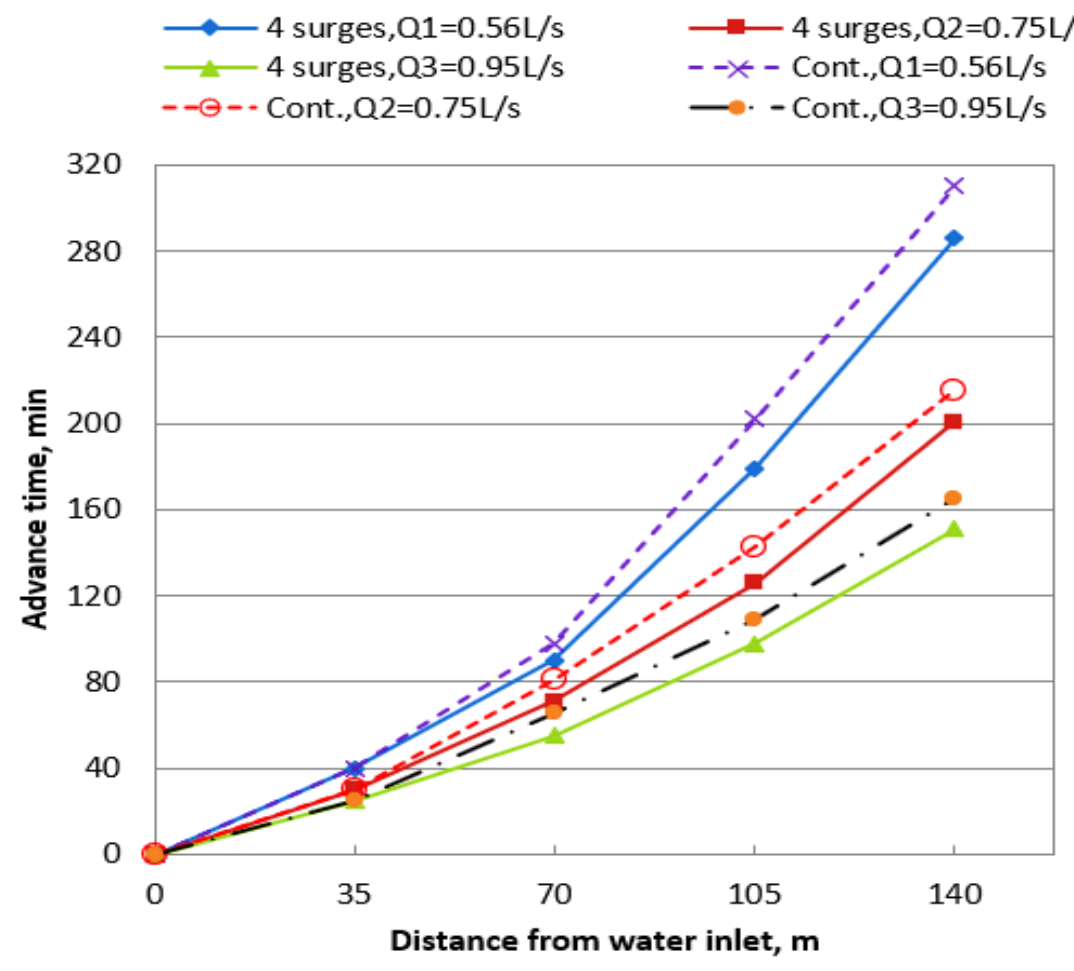

Figure 5: Advance time Vs distance from water inlet at different discharge rates with 5 surges and continuous flow irrigation

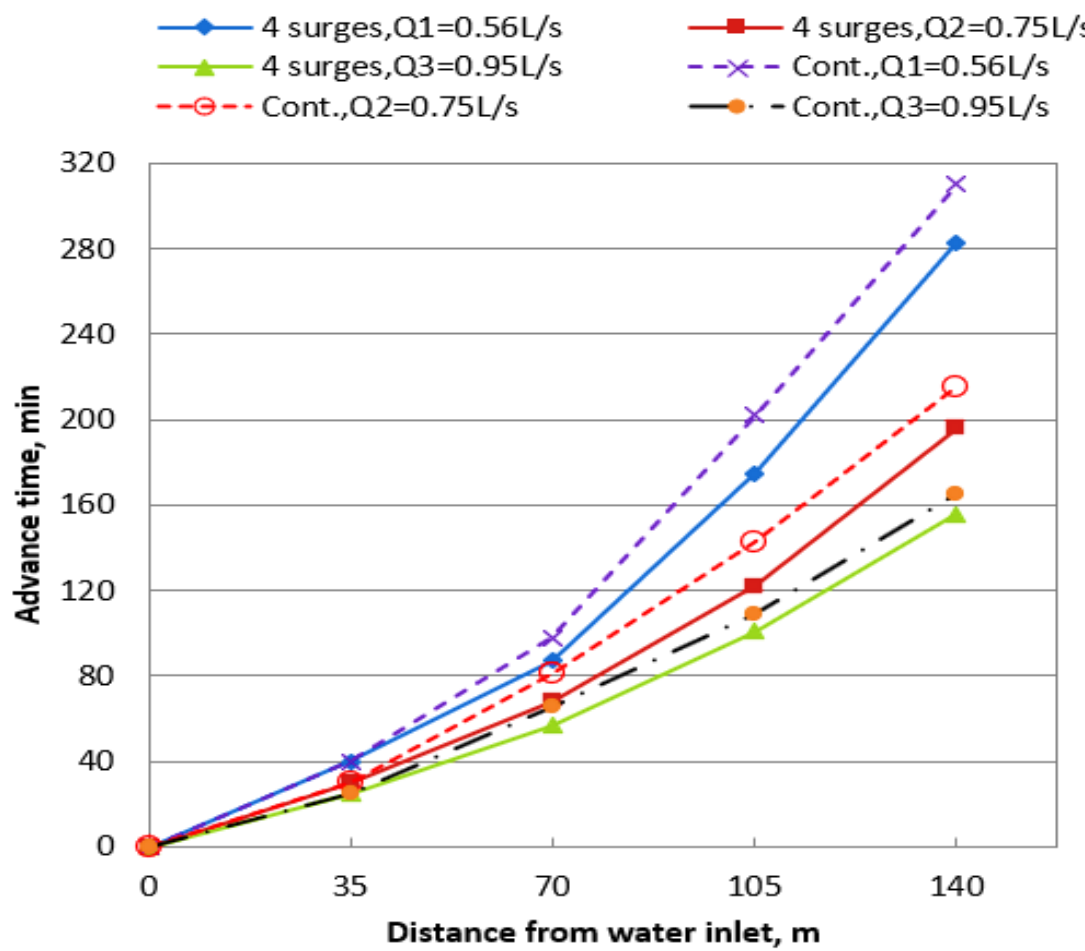

Figure 6: Advance time Vs distance from water inlet at different discharge rates with 6 surges and continuous flow irrigation

As a result, less water is lost to deep percolation at the beginning of the row and the water can advance faster down the furrow.

2. Chemicals application efficiency: The highest values of chemicals application efficiencies were obtained under surge flow technique which were 91 and $89 \%$ with 5 surges during $3^{\text {rd }}$ 
and $4^{\text {th }}$ injected surge with chemicals at $0.56 \mathrm{~L} / \mathrm{s}$ respectively, and was $91 \%$ with 6 surges during $4^{\text {th }}$ injected surge with chemicals at $0.56 \mathrm{~L} / \mathrm{s}$, while the lowest values were occurred under continuous irrigation which were 61,53 and $50 \%$ at discharge $0.56,0.75$ and $0.95 \mathrm{~L} / \mathrm{s}$, respectively as presented in Table 7. The application efficiency for the treatments of 4 surges increased during $3^{\text {rd }}$ injected surge with chemicals compared with $2^{\text {nd }}$ injected surge which were 70,68 and $63 \%$ under $2^{\text {nd }}$ injected surge and increased to 80,75 and $72 \%$ under $3^{\text {rd }}$ injected surge. These results may be due to the suitable injected time corresponding to a good distribution uniformity. however, it can be noticed that the treatments of 5 surges during $2^{\text {nd }}$ injected surge with chemicals produced lower chemicals application efficiency compared with $3^{\text {rd }}$ and $4^{\text {th }}$ injected surges which were 79,75 and $68 \% ; 91,85$ and $77 \%$; and 89,84 and $82 \%$ at discharge rates of $0.56,0.75$ and $0.95 \mathrm{~L} / \mathrm{s}$ during $2^{\text {nd }}, 3^{\text {rd }}$ and $4^{\text {th }}$ injected surges, respectively. While in the treatments of 6 surges, we find that the values of chemicals application efficiency increased from $2^{\text {nd }}$ to $3^{\text {rd }}$ to $4^{\text {th }}$ injected surges and decreased during $5^{\text {th }}$ injected surge, achieving values of 65,63 and $61 \% ; 81,79$ and 74\%; 91,86 and $83 \%$ and 78, 73 and $65 \%$ under $2^{\text {nd }}, 3^{\text {rd }}, 4^{\text {th }}$ and $5^{\text {th }}$ injected surges respectively. The influence of discharge rate on chemicals application efficiency, which declined when discharge rate was higher across the board for all treatments. The findings revealed that application efficiency ratings follow the same pattern in all circumstances. Also, during the $4^{\text {th }}$ injected surge with chemicals, the application efficiency values for both 5 and 6 surges treatments were very close, with 89, 84, and $82 \%$ for the 5 surges treatment and 91, 86, and $83 \%$ for the 6 surges treatment at the same flow rates. The results presented in Table 7 refer to the greatest values of chemicals application efficiency which was obtained under discharge rate of $0.56 \mathrm{~L} / \mathrm{s}$ with 5 and 6 surges during $3^{\text {rd }}$ and $4^{\text {th }}$ injected surge with chemicals, respectively. Water added with surge flow technique concentrated chemicals and minerals in the root zone of plants at approximately $60 \mathrm{~cm}$ and prevented them from leaching into ground water, which resulted in the lowest leaching values at the deeper depths. When water and fertilizer applications are efficient and uniformly distributed, there is very little surface runoff, as well as very little deep drainage and leaching below the crop root zone.

Table 7: Effect of irrigation technique, discharge and fertilizer injection method on chemicals application efficiency

\begin{tabular}{|c|c|c|c|c|c|}
\hline \multirow{3}{*}{$\begin{array}{l}\text { No. of } \\
\text { surges }\end{array}$} & \multirow{3}{*}{$\begin{array}{l}\text { Discharge, } \\
\mathrm{L} / \mathrm{s}\end{array}$} & \multirow{2}{*}{\multicolumn{4}{|c|}{$\frac{\text { Chemicals application efficiency, } \%}{\text { Injected surge }}$}} \\
\hline & & & & & \\
\hline & & $2^{\text {nd }}$ & $3^{\text {rd }}$ & $4^{\text {th }}$ & $5^{\text {th }}$ \\
\hline \multirow{3}{*}{4 surges } & 0.56 & 70 & 80 & - & - \\
\hline & 0.75 & 68 & 75 & - & - \\
\hline & 0.95 & 63 & 72 & - & - \\
\hline \multirow{3}{*}{5 surges } & 0.56 & 79 & 91 & 89 & - \\
\hline & 0.75 & 75 & 85 & 84 & - \\
\hline & 0.95 & 68 & 77 & 75 & - \\
\hline \multirow{3}{*}{6 surges } & 0.56 & 65 & 81 & 91 & 78 \\
\hline & 0.75 & 63 & 79 & 86 & 73 \\
\hline & 0.95 & 61 & 74 & 83 & 65 \\
\hline \multirow{3}{*}{$\begin{array}{l}\text { Continuous } \\
\text { flow }\end{array}$} & 0.56 & \multicolumn{4}{|c|}{61} \\
\hline & 0.75 & \multicolumn{4}{|c|}{53} \\
\hline & 0.95 & \multicolumn{4}{|c|}{50} \\
\hline
\end{tabular}


3. Water productivity: Water productivity is a common way to describe how much water a crop uses. Water productivity can be defined as the ratio of crop yield to water applied. When compared to other treatments, the 6 surges treatment produced the highest water productivity $\left(1.83 \mathrm{~kg} / \mathrm{m}^{3}\right)$, as shown in Table 8 .

Table 8: Effect of number of surges, discharge and fertilizer injected surge on water productivity

\begin{tabular}{|c|c|c|c|c|}
\hline $\begin{array}{l}\text { No. of } \\
\text { surges }\end{array}$ & $\begin{array}{c}\text { Discharge, } \\
\text { L/s }\end{array}$ & $\begin{array}{c}\text { Fertilizer } \\
\text { injected } \\
\text { surge }\end{array}$ & $\begin{array}{c}\text { Water } \\
\text { productivity, } \\
\mathrm{kg} / \mathrm{m}^{3}\end{array}$ & $\begin{array}{c}\text { Percentage } \\
\text { of increase, } \\
\%\end{array}$ \\
\hline \multirow{6}{*}{4} & \multirow{2}{*}{0.56} & $2^{\text {nd }}$ & 1.19 & 36.782 \\
\hline & & $3^{\text {rd }}$ & 1.24 & 42.529 \\
\hline & \multirow{2}{*}{0.75} & $2^{\text {nd }}$ & 1.32 & 32.000 \\
\hline & & $3^{\text {rd }}$ & 1.34 & 34.000 \\
\hline & \multirow{2}{*}{0.95} & $2^{\text {nd }}$ & 1.42 & 30.275 \\
\hline & & $3^{\text {rd }}$ & 1.45 & 33.028 \\
\hline \multirow{9}{*}{5} & \multirow{3}{*}{0.56} & $2^{\text {nd }}$ & 1.44 & 65.517 \\
\hline & & $3^{\text {rd }}$ & 1.45 & 66.667 \\
\hline & & $4^{\text {th }}$ & 1.45 & 66.667 \\
\hline & \multirow{3}{*}{0.75} & $2^{\text {nd }}$ & 1.54 & 54.000 \\
\hline & & $3^{\mathrm{rd}}$ & 1.56 & 56.000 \\
\hline & & $4^{\text {th }}$ & 1.55 & 55.000 \\
\hline & \multirow{3}{*}{0.95} & $2^{\text {nd }}$ & 1.72 & 57.798 \\
\hline & & $3^{\text {rd }}$ & 1.73 & 58.716 \\
\hline & & $4^{\text {th }}$ & 1.73 & 58.716 \\
\hline \multirow{12}{*}{6} & \multirow{4}{*}{0.56} & $2^{\text {nd }}$ & 1.47 & 68.966 \\
\hline & & $3^{\text {rd }}$ & 1.49 & 71.264 \\
\hline & & $4^{\text {th }}$ & 1.50 & 72.414 \\
\hline & & $5^{\text {th }}$ & 1.49 & 71.264 \\
\hline & \multirow{4}{*}{0.75} & $2^{\text {nd }}$ & 1.67 & 67.000 \\
\hline & & $3^{\text {rd }}$ & 1.71 & 71.000 \\
\hline & & $4^{\text {th }}$ & 1.72 & 72.000 \\
\hline & & $5^{\text {th }}$ & 1.71 & 71.000 \\
\hline & \multirow{4}{*}{0.95} & $2^{\text {nd }}$ & 1.80 & 65.138 \\
\hline & & $3^{\text {rd }}$ & 1.81 & 66.055 \\
\hline & & $4^{\text {th }}$ & 1.83 & 67.890 \\
\hline & & $5^{\text {th }}$ & 1.79 & 64.220 \\
\hline \multirow{3}{*}{$\begin{array}{l}\text { Continuous } \\
\text { flow }\end{array}$} & 0.56 & - & 0.87 & - \\
\hline & 0.75 & - & 1.00 & - \\
\hline & 0.95 & - & 1.09 & - \\
\hline
\end{tabular}


At the same number of surges, increasing the discharge rate increased the value of water productivity. increasing the number of surges from 4 to 6 the values of water productivity increased from $1.24,1.34$ and $1.45 \mathrm{~kg} / \mathrm{m}^{3}$, to $1.49,1.71$ and $1.81 \mathrm{~kg} / \mathrm{m}^{3}$ for the discharge rates of $0.56,0.75$ and $0.95 \mathrm{~L} / \mathrm{s}$, respectively, under 4 and 6 surges treatment through at the same injected surge with chemicals of $3^{\text {rd }}$. But the results were close between 5 and 6 surges treatments in terms of water productivity which were $1.45,1.56$ and $1.73 \mathrm{~kg} / \mathrm{m}^{3}$ under the 5 surges treatment at the same injected surge with chemicals $\left(3^{\text {rd }}\right)$. When served with 6 surges of chemicals, the highest water productivity was $1.83 \mathrm{~kg} / \mathrm{m}^{3}$, with a discharge rate of $0.95 \mathrm{~L} / \mathrm{s}$ and increase of $67.890 \%$ by comparison with a continuous flow rate. The maximum increase percent of water productivity was $72.414 \%$ with a discharge rate of 6 surges, $0.56 \mathrm{~L} / \mathrm{s}$ and chemicals $\left(4^{\text {rd }}\right)$ by comparison with a continuous flow rate. High grain yield and high-water productivity may be attributable to surge flow irrigation treatments because they had a more uniform water distribution with less losses to deep percolation. These findings were obtained by many others such as Eid (1998), Ismail (2006), Sharaby (2015) and Khalifa (2019). As a result of soil aeration and moisture distribution uniformity along the furrow, these results may have been achieved by encouraging plants to grow. The discharge, number of surges, and fertilizer injection times were highly significant affecting factors on water productivity, according to the analysis of variance. Water productivity was not significantly affected by their interaction, as shown in Table 9. Because surge flow irrigation treatments had higher water distribution uniformity, fewer water losses by deep percolation and less amount of water applied, these results may be attributed to high grain yields and high fertilizer efficiency.

Table 9: Analysis of variance for water productivity

\begin{tabular}{|c|c|c|c|}
\hline Source & DF & MS & F \\
\hline Main plots & & & \\
\hline Blocks & 2 & 0.0075 & $001.3157 \mathrm{~ns}$ \\
\hline Q & 2 & 0.2035 & $035.7017 * *$ \\
\hline Main plots errors & 4 & 0.0057 & \\
\hline N.S & 3 & 0.8240 & $174.0845^{* *}$ \\
\hline N.S $\times Q$ & 6 & 0.0032 & $000.6831 \mathrm{~ns}$ \\
\hline Error & 18 & 0.0047 & \\
\hline Total & 35 & & \\
\hline
\end{tabular}

$\mathrm{Q}=$ discharge rate $; * *$ high significant; N.S = number of surges; ns=non-significant

4. Cost analysis of irrigation: In Egypt irrigation water is not priced and the government covers all expenses of water delivery up to the fields. The cost analysis of corn crop yield production indicated that the yield of corn crop differs according to irrigation and fertilization treatments. The total irrigation costs are a major capital impute for most farms. The capital and annual costs (fixed and operating) of different irrigation systems and irrigation treatments are presented in Table 10. The total irrigation cost decreased by increasing irrigation treatments from 4 to 6 pulses. Also, the total costs decreased by increasing discharge rate from 0.56 to $0.95 \mathrm{~L} / \mathrm{s}$ for all treatments. Data showed that by using surge flow technique, the 
total costs decreased compared with continuous flow irrigation. The highest value of costs was $924.5 \mathrm{~L} . \mathrm{E} / \mathrm{fed} / \mathrm{season}$ under discharge rate of $0.56 \mathrm{~L} / \mathrm{s}$ with continuous flow irrigation compared with the lowest costs of $679.7 \mathrm{~L}$.E/fed/season through 6 pulses treatment at a discharge rate of $0.95 \mathrm{~L} / \mathrm{s}$. On the other hand, the higher water application rate and consumed energy resulted in higher annual operating costs that led to increase total annual costs. The highest value of saving total cost $(13.1 \%)$ was obtained by using surge flow technique with 6 pulses treatment at discharge of $0.75 \mathrm{~L} / \mathrm{s}$.

Table 10: Irrigation cost under different irrigation treatments

\begin{tabular}{|c|c|c|c|c|c|c|c|c|}
\hline 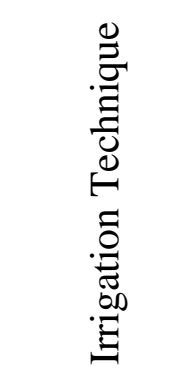 & 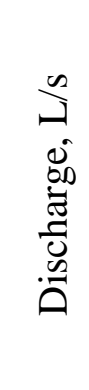 & 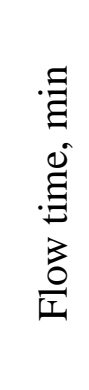 & 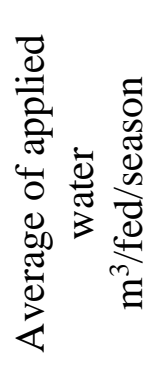 & 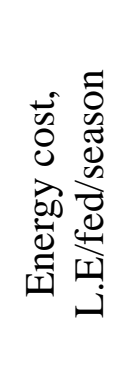 & 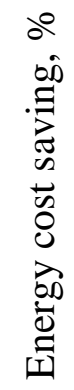 & 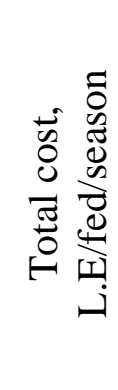 & 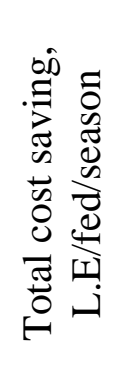 & 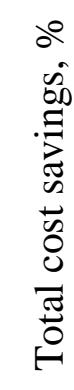 \\
\hline \multirow{3}{*}{ 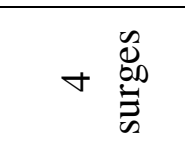 } & 0.56 & 261 & 2705 & 313.2 & 16 & 865.7 & 58.8 & 6.4 \\
\hline & 0.75 & 177 & 2498.1 & 212.4 & 18 & 764.9 & 72.6 & 8.7 \\
\hline & 0.95 & 129 & 2340.8 & 154.8 & 22 & 707.3 & 43.2 & 5.8 \\
\hline \multirow{3}{*}{ 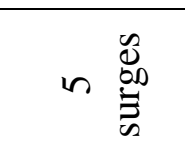 } & 0.56 & 246 & 2575.4 & 295.2 & 21 & 847.7 & 76.8 & 8.3 \\
\hline & 0.75 & 161 & 2313.0 & 193.2 & 25 & 745.7 & 91.8 & 11.0 \\
\hline & 0.95 & 111 & 2076.9 & 133.2 & 33 & 685.7 & 64.8 & 8.6 \\
\hline \multirow{3}{*}{ 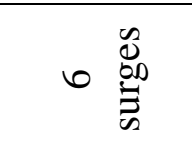 } & 0.56 & 233 & 2463.1 & 279.6 & 25 & 832.1 & 92.4 & 10.0 \\
\hline & 0.75 & 146 & 2139.4 & 175.2 & 32 & 727.7 & 109.8 & 13.1 \\
\hline & 0.95 & 106 & 2003.7 & 127.2 & 36 & 679.7 & 70.8 & 9.4 \\
\hline \multirow{3}{*}{$\begin{array}{l}\text { Continuous } \\
\text { Flow }\end{array}$} & 0.56 & 310 & 3128.4 & 372 & - & 924.5 & - & - \\
\hline & 0.75 & 215 & 2937.9 & 258 & - & 837.5 & - & - \\
\hline & 0.95 & 165 & 2868.4 & 198 & - & 750.5 & - & - \\
\hline
\end{tabular}

\section{CONCLUSION}

As a development for conventional furrow irrigation methods, adding fertilizers and various chemicals to surge (pulse) irrigation technique has been proposed in this research. Increasing the number of pulses and chemical pulse injections had a positive impact on water productivity, as well as on the application efficiency and various chemicals in the root zone. Other effects of salinization include preventing the loss of various chemicals (fertilizers, pesticides, etc.) from the ground, as well as preventing soil leakage and groundwater pollution. A comparison of water productivity with continuous flow irrigation at the same conditions using six surges and injecting fertilizer into the fourth surge showed an increase of 72.414\% The highest cost was 924.5L.E/fed/season which was recorded with continuous flow irrigation at a discharge rate of $0.56 \mathrm{~L} / \mathrm{s}$, while the lowest cost of $679.7 \mathrm{~L} . \mathrm{E} / \mathrm{fed} / \mathrm{season}$ was recorded with the six pulses treatment at a discharge rate of $0.95 \mathrm{~L} / \mathrm{s}$. in the Middle Delta region of Egypt, it is recommended to use a fertigation injection technique that uses the $2^{\text {nd }}$, $3^{\text {rd }}, 4^{\text {th }}$, and $5^{\text {th }}$ surges for a total of six surges and a discharge rate of $0.95 \mathrm{~L} / \mathrm{s}$ on a furrow irrigation length of around $140 \mathrm{~m}$. 


\section{REFERENCES}

Allen, R. G.; L. S. Pereira; D. Raes and M. Smith (1998). Crop Evapotranspiration Guidelines for computing crop water requirements. FAO Irrigation and Drainage paper 56. FAO, Rome, 300(9), D05109.

Amer, M. H., Abd El Hafez, S. A., and Abd El Ghany, M. B. (2017). Water Saving in Irrigated Agriculture in Egypt. LAP LAMBERT Academic Publishing: Saarbrücken, Germany.pp, 7 and 11.

Amer, M., and Attafy, T. (2017). Effect of surge flow on some irrigation indices of furrow irrigation system. Journal of Soil Sciences and Agricultural Engineering, Mansoura University ,8(12), 703-708.

Boldt, A. L., Watts, D. G., Eisenhauer, D. E., and Schepers, J. S. (1994). Simulation of water applied nitrogen distribution under surge irrigation. Transactions of the ASAE, 37(4), 1157-1165.

Doorenbos, J. and W. O. Pruitt (1977). Crop Water Requirements. FAO irrigation and drainage paper 24. Land and Water Development Division, FAO, Rome, 144.

Ebrahimian, H., Keshavarz, M. R., and Playán Jubillar, E. (2014). Surface fertigation: a review, gaps and needs. Spanish Journal of Agricultural Research 2014 12(3): 820837

Eid, S. M. (1998). Surge flow irrigation for corn and wheat under different land levelling practices in heavy clay soils. Ph. D. Thesis, Soil Sci. Dept., Fac. of Ag., Tanta University.

Eldeiry, A. A., Garcia, L. A., El-Zaher, A. S. A., and Kiwan, M. E. S. (2005). Furrow irrigation system design for clay soils in arid regions. Applied engineering in agriculture, 21(3), 411-420.

FAO (2015). World Fertilizer Trends and Outlooks to 2018. Rome: Food and Agriculture Organization of the United Nations. [Google Scholar].

Gascho, G. J. and A. M. Mashali (1991). Soil-Water nutrient interaction under fertigation system. FAO, Consultation on fertigation/Chemigation, 8 - 11 Sept., Cairo, Egypt: 8398.

Hoffman, G. J.; T. A. Howell and K. H. Solomon (1992). Management of farm irrigation systems. ASAE Monograph No. 9 Ed. Hoffman, et al. ASAE, USA. pp: 1040.

Horst, M. G.; S. S. Shamutalov; J. M. Goncalves and L. S. Pereira (2007). Assessing Impacts of Surge flow Irrigation on Water Saving and Productivity of Cotton. Agricultural Water Management, vol. 87: 115-127.

Hou, Z.; P. L; B. Li; J. Gong and Y. Wang (2007). Effects of fertigation scheme on N uptake and N use efficiency in cotton. Plant Soil290:115-126.

Humpherys, A. S. (1989). Surge irrigation: II An overview. ICID Bulletin 38(2): 35-48. 
Ismail, S. M. (2004). Effectiveness of surge flow irrigation in Egypt. Ph. D. thesis, Wageningen University, The Netherlands.

Ismail, S. M. (2006). Effect of tillage on water advance and distribution under surge and continuous furrow irrigation for cotton in Egypt. Irrigation and Drainage Journal, 55(2): 191-199.

James, L. G. (1988). Principle of Farm Irrigation System Design. John Willey and sons. New York.

Kanber R.; H. Koksal; S. Onder; S. Kapur and S. Sahan (2001). Comparison of surge and continuous furrowmethods for cotton in the Harran plain. Agricultural Water Management, Vol. 47: 119-135.

Keller, J. and D. Karameli (1974). Trickle irrigation design parameters. ASAE 17(4): 512684.

Khalifa, E., A. Okasha, S. Shawat (2019). Development of surface irrigation using surge irrigation technique. Fresenius Environmental Bulletin, 28(4), 3121-3130.

Khalifa, E., M. Mahmoud, and M. Khatab (2019). Effect of different chemicals injected surges on chemicals application and distribution uniformity through furrow irrigation in clay soil under delta region of Egypt. Fresenius Environmental Bulletin, 28(9), 6444-6452

Kifle, M.; K. Tilahun and E. Yazew (2008). Evaluation of surge flow furrow irrigation for onion production in a semiarid region of Ethiopia. Irrigation science, 26(4), 325-333.

Mohammadi, A., Besharat, S., and Abbasi, F. (2019). Effects of irrigation and fertilization management on reducing nitrogen losses and increasing corn yield under furrow irrigation. Agricultural Water Management, 213, 1116-1129.

Moustafa, M.M. (2013). Surge flow chemigation. Egyptian Journal of Agricultural Research (Special Issue / 3rd International Conference on Agricultural and Biological Engineering) November 2013. "Engineering Applications for Sustainable Agricultural Development", vol. 91, No. 2 (a), pp. 255-272.

Ojaghlou, H., Sohrabi, T., Abbasi, F., and Javani, H. (2020). Development and evaluation of a water flow and solute transport model for furrow fertigation with surge flow. Irrigation and Drainage, 69(4), 682-695.

Perea, H.; E. Bautista, D. J. Hunsaker; T. S. Strelkoff, C. Williams, and F. J. Adamsen (2011). Nonuniform and Unsteady Solute Transport in Furrow Irrigation. II. Description of Filed Experiments and Calibration of Infiltration and Roughness Coefficients. J. Irrig. Drain. Eng., 137(5): 315-326.

Rao, B. K., Bhatnagar, P. R., Kamble, T., Kurothe, R. S., Mishra, P. K., Sharma, R., Kumar A. and Pande, V. C. (2019). Surge-flow alternate furrow irrigation for 
enhancing water productivity in semiarid regions. Indian Journal of Agricultural Sciences, 89(12), 1999-2002.

Rasoulzadeh, A. and A. R. Sepaskhah (2003). Scaled Infiltration Equations for Furrow Irrigation, Biosystems Engineering. DOI: 10.1016/j. Biosystems Eng. 2003.07.004.86(3): 375-383.

Sabillon, G. N.; G. P. Merkley; (2004). Fertigation guidelines for furrow irrigation. Span J. Agr. Res. 2(4):576-587.

Sharaby, N. N. (2015). Studying engineering technique for irrigation systems development. M. Sc. Thesis, Ag. Eng. Dept., Fac. of Ag., Kafrelsheikh Univ., Egypt.

Shock, C. C. and T. Welch (2011). Surge Irrigation, Sustainable Agriculture Techniques, Oregon State University, Department of Crop and Soil Science Ext/CrS 135.

Sial, J. K., Khan, M. A., and Ahmad, N. (2006). Performance of surge irrigation under borders. Pak. J. Agri. Sci, 43(3-4), 186-192.

Siyal A. A.; K. L. Bristow; and J. Simunek (2012) Minimizing nitrogen leaching from furrow irrigation through novel fertilizer placement and soil management strategies. Agricultural Water Management 115:242-251

Smith, R. J.; S. R. Raine and J. Minkovich (2005). Irrigation application efficiency and deep drainage potential under surface irrigated cotton. Agricultural Water Management, 71(2): 117-130.

Soroush, F.; F. B. Mostafazadeh; S. F. Mousavi and F. Abbasi (2012). Solute distribution uniformity and fertilizer losses under mean drainage and standard furrow irrigation methods. Aust. J. Crop Sci. 6(5):884-890.

Spencer, G. D., Krutz, L. J., Falconer, L. L., Henry, W. B., Henry, C. G., Larson, E. J., Pringle, H.C., Bryant, C.J. and Atwill, R. L. (2019). Irrigation Water Management Technologies for Furrow-Irrigated Corn that Decrease Water Use and Improve Yield and On-Farm Profitability. Crop, Forage \& Turfgrass Management, 5(1), 1-8. https://doi.org/10.2134/cftm2018.12.0100.

USDl (1993). Report of the United States Department of Interior, Bureau of Reclamation Cooperative Agreement for Surge flow irrigation Research and Development Program, Grand Valley Unit. Colorado State University, Colorado, USA.

Valipour, M. (2013). Increasing irrigation efficiency by management strategies: Cutback and surge irrigation. ARPN Journal of Agricultural and Biological Science. 8 (1): 35-43.

Worth, B. and J. Xin (1983). Farm mechanization for profit, Granada publishing. UK. P. 269. Google Scholar.

Zamora-Re, M. I., Dukes, M. D., Hensley, D., Rowland, D., and Graham, W. (2020). The effect of irrigation strategies and nitrogen fertilizer rates on maize growth and grain yield. Irrigation Science, 38(4), 461-478. 


\section{تأثير التسميد بتقتية السريان النبضي على كفاءة الاضافة وانتاجية المياه وتكلفة الري لإنتاج محصول على الذاعرة \\ عبد العزيز محمد عكاشة'، السعد محمد خليفةّ، مصطفي محمود مصطفيّ و محمد صبحي خطاب؛}

' أستاذ مساعد ـ قسم الهندسة الزر اعية ـ كلية الزر اعة ـ جامعة كفر الثيخ ـ مصر.

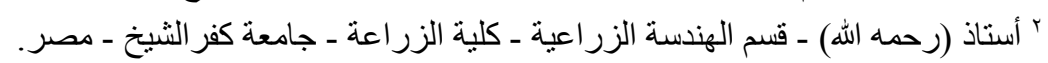

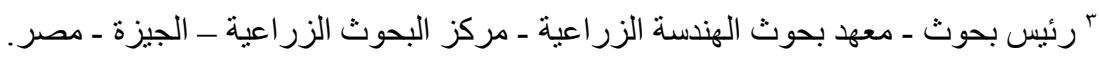

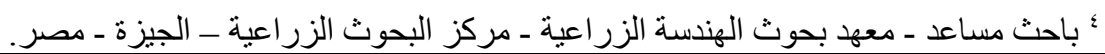

الملخص العربي

يعتبر استخدام التسميد من خلال إسلوب الري النبضي ذات نأثير في رفع انتاجية المياه وتقليل تكاليف الري بالمقارنة بالري المستمر للخطوط في تربة طينية لإنتاج

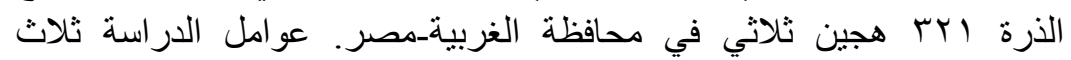

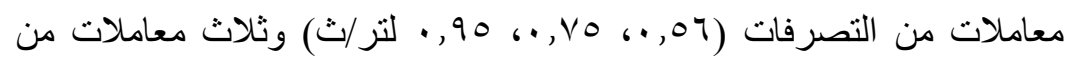

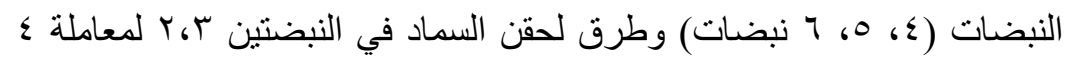

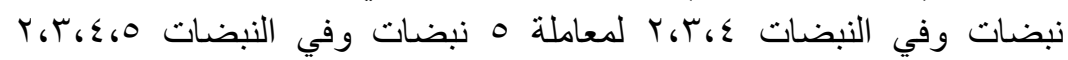
لمعاملة 7 نبضات. زمن غلق المياه • 1 دقائق و الري المستمر بالخطوط معاملة

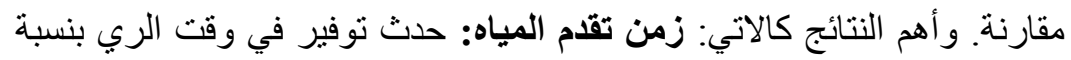
ل

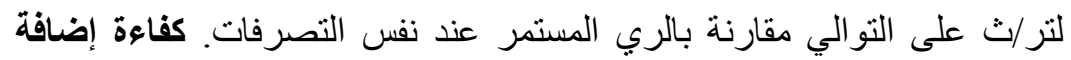

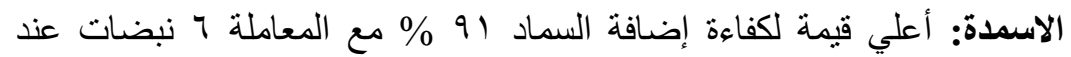

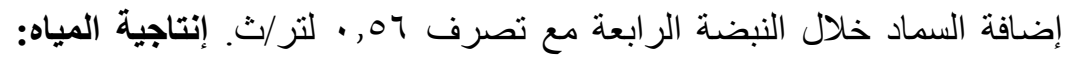

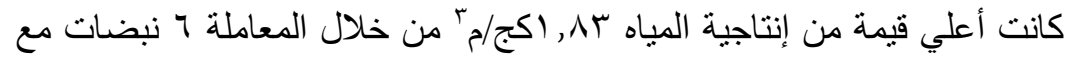
تصرف 90, • لتر/ث عند التسميد في النبضة الرابعة مقارنة بجميع المعاملات التهات التهات الأخرى التكلفة الاقتصادية للري: تنخفض تكلفة الري باستخدام تقنية الري

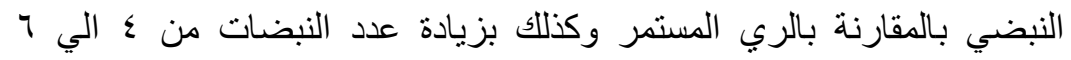

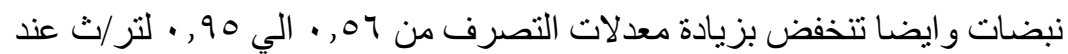

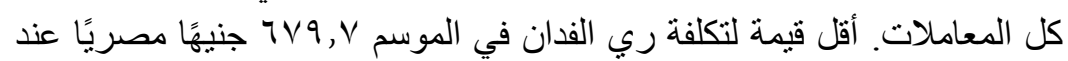
استخدام الري النبضي 7 نبضات بمعدل تصرف 90 , • لتر/ث. نوصي باستخدام

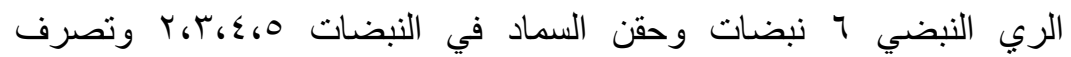
9 , •لتر/ت للخطوط الري الطويلة والتي لا تتعدي • ــ ام لمنطقة وسط الدلتا بجمهورية مصر العربية.

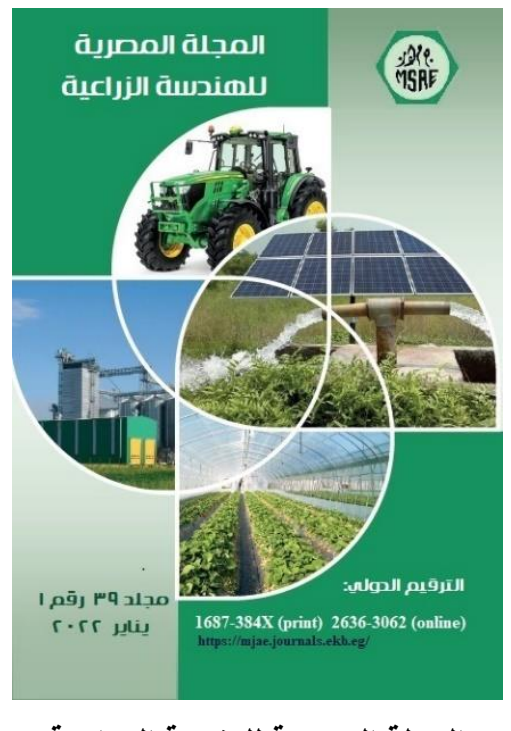

C المجلة المصرية للهنسة الزراعية

الكلمات المفتاحية: السريان النبضي؛ كفاءة اضافة الكيماويات؛ انتاجية المياه؛ تكلفة الري؛ محصول الذرة. 